JKAU: Eng. Sci., Vol. 20 No.1, pp: $61-73$ (2009 A.D. / 1430 A.H.)

\title{
Effect of Sand Replacement and Silica Fume Addition on Chloride Ion Permeability of Lightweight Concrete
}

\author{
Faiz Abdullah M. Mirza \\ Civil Engineering Department, Umm Al-Qura University, \\ Makkah Al-Mukarramah, Saudi Arabia
}

\begin{abstract}
This paper was conducted to study the behavior of lightweight concrete, incorporating local lightweight aggregate (LWA), in terms of chloride ion permeability at different ages. The effect of lightweight fine aggregate replacement by normal weight sand $(0,25,50$ and $75 \%$ by volume) was investigated. Constant level of silica fume content ( $10 \%$ by weight of cement) as an addition was also considered. Although results showed that the use of porous lightweight aggregate did not lower the permeability of lightweight concrete, test results indicated a decrease in chloride ion permeability as a result of increasing sand replacement for all types of mixes up to 360 days. The reduction in chloride ion permeability was attributed to the presence of the sand which appeared to decrease the porosity of LWC, the reduction in the chloride diffusion coefficient was observed to be as much as $50 \%$. Moreover, the addition of silica fume caused further reductions in chloride ion permeability due to the progression in maturity of LWC, especially after one year of continuous hydration.
\end{abstract}

Keywords: Lightweight concrete, permeability, silica fume, chloride ion, sand replacement.

\section{Introduction}

Material transport properties, especially permeability, affect the durability and integrity of a structure. High permeability, due to porosity or cracking, provides an access for water, chlorides, and other corrosive agents. If such agents reach reinforcing bars, the bars corrode, thus compromising the ability of the structure to withstand loads, which eventually leads to structural failure. Therefore, there has been an interest 
both in determining the permeability of lightweight concrete compared with normal weight concrete, and in the improvement of this type of concrete with lower permeability ${ }^{[1]}$.

Lightweight aggregate particles are generally more porous and penetrable than normal weight aggregate particles and this, also common with normal weight aggregates of higher porosities, which allow more diffusion of fluids. Therefore many researchers study the resistance of lightweight concrete to water penetration and accelerated chloride penetration. Test results explained that the permeability of lightweight concrete appears to be low, but it may be higher than that of normal strength concrete at similar strength level ${ }^{[2]}$. The permeability of highstrength lightweight concrete appears to be more dependent on the porosity of the mortar matrix than on the porosity of the lightweight aggregate. A direct relationship between water permeability and accelerated rate of chloride penetration was observed ${ }^{[3]}$.

The water permeability and chloride penetration in lightweight and normal weight aggregate concretes (LWC and NWC) were conducted ${ }^{[4,5]}$. In these studies, water-cementitous materials ratio $(\mathrm{w} / \mathrm{c})$ of 0.35 , and 0.55 , and silica fume content of $0 \%$ and $10 \%$ as a partial replacement of cement were used to obtain concrete with different strength levels. The results indicated that at the strength level of 30-40 $\mathrm{MPa}$, the water permeability of the LWC with w/c of 0.55 was lower than that of the NWC. However, at $\mathrm{w} / \mathrm{c}$ of 0.35 , the water permeability of LWC and NWC was not significantly different. The resistance of the LWC to chloride ion penetration was similar to that of the corresponding of the NWC with the same w/c ratio. Finally, the results indicated that the LWC would probably have lower water permeability and better resistance to chloride ion penetration than NWC with equivalent 28-day compressive strength.

Experimental studies on the water permeability and chloride-ion penetrability of high-strength lightweight concrete (LWC) in comparison to that of high-strength normal-weight concrete (NWC) with or without silica fume was detected. The water permeability of the high-strength LWC and NWC was of the same order. The resistance of the LWC to the chloride penetration was similar to that of the corresponding NWC both in the normal-strength and high-strength levels ${ }^{[6-8]}$. 
As the compressive strength of the LWC was lower than that of the corresponding NWC, experimental results indicated that for a given 28-day strength, the LWC would probably have high resistance to water and chloride-ion penetration than the $\mathrm{NWC}^{[9]}$. The results also indicated that the resistance to the chloride penetration does not seem to be correlated to the water permeability of the concrete. Although chloride permeability of low density LWC concrete decreased with age of concrete, it was found that the concrete was not dense enough to stop the chloride ion to penetrate through the concrete before the concrete mature at age of 90 days ${ }^{[10,11]}$.

Modification of the interfacial transition zone between the aggregate and the bulk matrix of concrete by using silica fume is a common technique applied nowadays to improve concrete properties ${ }^{[12]}$. Silica fume acts as a micro filler, filing the transition zone between the aggregate surface and the bulk cement matrix, followed by pozzolanic reaction at the same place ${ }^{[13]}$. When porous aggregate is involved, as in lightweight aggregate used in this study, the interfacial transition zone extends from a certain distance below the surface of the aggregate particle out to the bulk cement ${ }^{[14]}$. Finally, it can be concluded that incorporating silica fume in structural lightweight concrete mixes significantly reduces the chloride ion penetration dye to the above mentioned mechanism (filler and pozzolanic effects) of concrete. Consequently, improve the durability properties of concrete.

The present work covers the behavior of structural lightweight concrete made of local lightweight aggregate with different percentage of sand content at constant level of silica fume in terms of chloride ion permeability up to one year. The tests were carried out to evaluate the effect of sand replacement ratios and silica fume content in lightweight concrete on chloride ion penetration for different.

\section{Experimental Work}

The long term behavior of lightweight aggregate concrete, made with local lightweight aggregate, up to 360 days was studied in terms of chloride ion penetration. The main variables taken into consideration in this work were the fine aggregate content $(0,25,50,75 \%)$, and silica fume as an addition of $10 \%$ by weight of cement. The experimental program is shown in Table 1. 
Table 1. Experimental program for light weight concrete mixes.

\begin{tabular}{|c|c|c|c|c|c||}
\hline \multirow{2}{*}{$\begin{array}{c}\text { Age } \\
\text { (days) }\end{array}$} & \multirow{2}{*}{ Mix type } & \multicolumn{4}{|c|}{ Normal weight fine aggregate ( \% ) } \\
\cline { 2 - 6 } & & $\mathbf{0}$ & $\mathbf{2 5}$ & $\mathbf{5 0}$ & $\mathbf{7 5}$ \\
\hline \multirow{2}{*}{28} & $\mathrm{~A}$ & $*$ & $*$ & $*$ & $*$ \\
\cline { 2 - 6 } & $\mathrm{B}$ & $*$ & $*$ & $*$ & $*$ \\
\hline \multirow{2}{*}{90} & $\mathrm{~A}$ & $*$ & $*$ & $*$ & $*$ \\
\cline { 2 - 6 } & $\mathrm{B}$ & $*$ & $*$ & $*$ & $*$ \\
\hline \multirow{2}{*}{360} & $\mathrm{~A}$ & $*$ & $*$ & $*$ & $*$ \\
\cline { 2 - 7 } & $\mathrm{B}$ & $*$ & $*$ & $*$ & $*$ \\
\hline
\end{tabular}

*Three samples were conducted for compression.

- Mix A without silica fume.

- Mix B with an addition of $10 \%$ silica fume by weight of cement.

\section{Materials Properties}

Ordinary portland cement (Type I) with $3.16 \mathrm{~g} / \mathrm{cm}^{3}$ density is used, the level of cement content was kept constant at $400 \mathrm{~kg} / \mathrm{m}^{3}$ in this work. Silica fume with $2.20 \mathrm{~g} / \mathrm{cm}^{3}$ density, $25.5 \mathrm{~m}^{2} / \mathrm{g}$ specific surface area, and $97.5 \% \mathrm{SiO}_{2}$ content is used at $10 \%$ by weight of cement as an addition to cement. The water to cement ratio (W/C) was 0.40 excluded the water absorbed by aggregate. Fine aggregate was natural sand with 2.62 specific gravity and 2.87 fineness modulus. The fine aggregate passed the ASTM requirements (C-33).

Pozzolanic natural lightweight aggregate (scoria) occurring in the Western Province of Saudi Arabia is volcanic in origin and is geologically categorized as pozzolanic scoria and tuff. This type of lightweight aggregate is available in different sizes, it was used as coarse aggregate, with different size of 5-20 mm. LWA has also been tested extensively at the quality control laboratories of Saudi Arabian Standards Organization (SASO). The results show that values for coarse and combined aggregate fall within the limit specified by ASTM C-332. Tests conducted by SASO on light weight concrete panels made from LWA yielded a thermal conductivity value of $0.140 \mathrm{~W} / \mathrm{m}-\mathrm{k}$ (less than 0.43 as required by ASTM C-332). The physical properties of LWA used in this research are given in Table 2 . 
Table 2 . Physical properties of LWA.

\begin{tabular}{||l|c||}
\hline \multicolumn{1}{||c|}{ Color } & Grayish/black \\
\hline Bulk density $\left(\mathrm{kg} / \mathrm{m}^{3}\right)$ for coarse aggregate & $615-800$ \\
\hline Bulk density $\left(\mathrm{kg} / \mathrm{m}^{3}\right)$ for fine aggregate & $850-1075$ \\
\hline Bulk specific gravity $(\mathrm{SSD})$ & 1.85 \\
\hline Oven dry specific gravity & 1.66 \\
\hline L-A abrasion value & $28-33$ \\
\hline Thermal conductivity of insolating concrete from cicolite & $0.140 \mathrm{~W} / \mathrm{m} \mathrm{k}$ \\
\hline Fire rating & 3 hours \\
\hline Noise attenuation & $3-6 \mathrm{~dB}$ \\
\hline \hline
\end{tabular}

\section{Test Samples and Test Method}

Hence, mix proportioning of lightweight concrete is generally accomplished by empirical method. Table 3 presents the mix proportions of all mixes used in this investigation.

Table 3. Mix proportions by weight for mix $\mathbf{A}^{1}$.

\begin{tabular}{|c|c|c|c|c|c|}
\hline $\begin{array}{c}\text { Sand } \\
\text { replacement } \\
(\%)\end{array}$ & $\begin{array}{c}\text { Cement } \\
(\text { kg ) }\end{array}$ & $\begin{array}{l}\text { Water } \\
(\mathrm{kg})^{2}\end{array}$ & $\begin{array}{c}\text { Light weight } \\
\text { coarse } \\
\text { aggregate } \\
(\mathrm{kg})\end{array}$ & $\begin{array}{l}\text { Light weight } \\
\text { fine aggregate } \\
(\mathbf{~ k g ~ ) ~}\end{array}$ & $\begin{array}{c}\text { Normal } \\
\text { weight fine } \\
\text { aggregate } \\
\text { (kg) }\end{array}$ \\
\hline 0 & 6 & 3.9 & 6.142 & 12.272 & 0 \\
\hline 25 & 6 & 3.9 & 6.142 & 9.204 & 4.72 \\
\hline 50 & 6 & 3.9 & 6.142 & 6.136 & 9.44 \\
\hline 75 & 6 & 3.9 & 6.142 & 3.068 & 14.16 \\
\hline
\end{tabular}

1. Mix B : silica fume were added at $10 \%$ by weight of cement. These are weight $\%$ not volume.

2. This weight included the needed to be observed by L.W.A.

The chloride ion permeability test was performed following the ASTM C-1202. The test method consisted of monitoring the amount of electrical current passed through 51-mm thick slices of 102-mm nominal diameter cores or cylinders during a 6-h period. All samples were cured in water for three days after demolding and tested at three different ages $(28,90$, and 360). A potential difference of $60 \mathrm{~V} \mathrm{dc}$ was maintained across the ends of the specimen, one of which was immersed in a sodium chloride solution, the other in a sodium hydroxide solution. The total 
charge passed, in Coulombs, has been found to be related to the resistance of the specimen to chloride ion penetration [AASHTO, T 259-8]. Figure 1 shows schematic of rapid chloride permeability test apparatus. The test results are then evaluated using the qualitative classification of Table 4 [AASHTO, T 259-8].

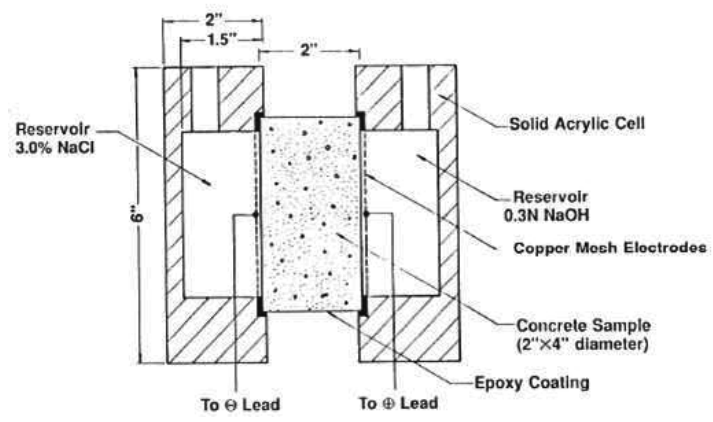

Fig. 1. chloride permeability test apparatus concrete.

Table 4. Chloride permeability classifications [AASHTO, T 259-8].

\begin{tabular}{||c|c|l||}
\hline $\begin{array}{c}\text { Charged } \\
\text { passed } \\
\text { (Coulombs) }\end{array}$ & $\begin{array}{c}\text { Chloride } \\
\text { permeability }\end{array}$ & \multicolumn{1}{c||}{ Typical of } \\
\hline$>4,000$ & High & $\begin{array}{l}\text { High water-cement ratio }(>0.6), \text { conventional } \\
\text { PCC }\end{array}$ \\
\hline $2,000-4,000$ & Moderate & $\begin{array}{l}\text { Moderate water-cement ratio }(0.4-0.5), \\
\text { conventional PCC. }\end{array}$ \\
\hline $1,000-2,000$ & Low & $\begin{array}{l}\text { Low water-cement ratio « 0.4), conventional } \\
\text { PCC. }\end{array}$ \\
\hline $100-1,000$ & Very low & $\begin{array}{l}\text { Latex-modified concrete, internally sealed } \\
\text { concrete. }\end{array}$ \\
\hline$<100$ & Negligible & $\begin{array}{l}\text { Polymer impregnated concrete, polymer } \\
\text { concrete. }\end{array}$ \\
\hline
\end{tabular}

\section{Results and Discussion}

The experimental results were analyzed in three sections. These sections explain the effect of sand replacement, silica fume addition and ages on the chloride ion permeability of structural lightweight concrete. The compressive strength was measured and found to be 25-30 MPa at age of 28 days. All tests results were reported in Table 5 and plotted in Fig. 2-4. 


\section{Effect of Sand Replacement}

Generally, it was observed that increasing the normal weight fine aggregate (sand) content, the chloride ion permeability decreased for all types of mixes. Much more effects on chloride ion permeability were recorded by the addition of $10 \%$ of silica fume to the light weight concrete mixes.

Table 5. Summary of chloride ion permeability test results for all mixes.

\begin{tabular}{|c|c|c|c|c|c|}
\hline \multirow{2}{*}{ Mix type } & \multicolumn{4}{|c|}{ Natural normal weight fine aggregate content ( \% ) } & \multirow{2}{*}{$\begin{array}{l}\text { Age } \\
\text { (day) }\end{array}$} \\
\hline & $\mathbf{0}$ & 25 & 50 & 75 & \\
\hline \multirow{4}{*}{ A } & 12196 & 9762 & 4781 & 2873 & \multirow{4}{*}{28} \\
\hline & 11384 & 8975 & 5380 & 2147 & \\
\hline & 11567 & 9365 & 4165 & 2397 & \\
\hline & 11987 & 8870 & 4680 & 2719 & \\
\hline \multirow{4}{*}{ B } & 10640 & 7225 & 3951 & 1874 & \multirow{4}{*}{28} \\
\hline & 9800 & 7534 & 3346 & 2165 & \\
\hline & 10060 & 6967 & 4008 & 1937 & \\
\hline & 10230 & 6890 & 3458 & 1792 & \\
\hline \multirow{4}{*}{ A } & 11642 & 9396 & 4508 & 2658 & \multirow{4}{*}{90} \\
\hline & 11498 & 8661 & 5126 & 1928 & \\
\hline & 10946 & 8964 & 3935 & 2148 & \\
\hline & 10925 & 8528 & 4316 & 2456 & \\
\hline \multirow{4}{*}{ B } & 10079 & 6831 & 3590 & 1611 & \multirow{4}{*}{90} \\
\hline & 9363 & 7113 & 3052 & 1603 & \\
\hline & 9631 & 6581 & 3687 & 1661 & \\
\hline & 9766 & 6415 & 3116 & 1539 & \\
\hline \multirow{4}{*}{ A } & 11490 & 9261 & 4250 & 2036 & \multirow{4}{*}{360} \\
\hline & 10780 & 8541 & 4317 & 2537 & \\
\hline & 10798 & 8832 & 4306 & 1812 & \\
\hline & 11347 & 8641 & 4558 & 2161 & \\
\hline \multirow{4}{*}{ B } & 9941 & 6979 & 2991 & 1512 & \multirow{4}{*}{360} \\
\hline & 9231 & 6600 & 3561 & 1520 & \\
\hline & 9492 & 6541 & 3463 & 1570 & \\
\hline & 9630 & 6722 & 3114 & 1679 & \\
\hline
\end{tabular}

The effect of sand replacement on the chloride ion permeability was illustrated in Fig. 2 for ages of 28, 90, and 360 days. From this figure it is clear that by increasing sand content up to $75 \%$, the chloride ion permeability decreases for all mixes and consequently improves the 
quality of concrete. The percent age of reduction in chloride ion permeability optimized at $75 \%$ sand replacement, For example the chloride ion permeability reduced form 7000 Coulombs to 2000 Coulombs by increasing the NW sand replacement from $25 \%$ to $75 \%$. At later ages similar rates of reduction in the values of chloride ion permeability were observed at 90 and 360 days.

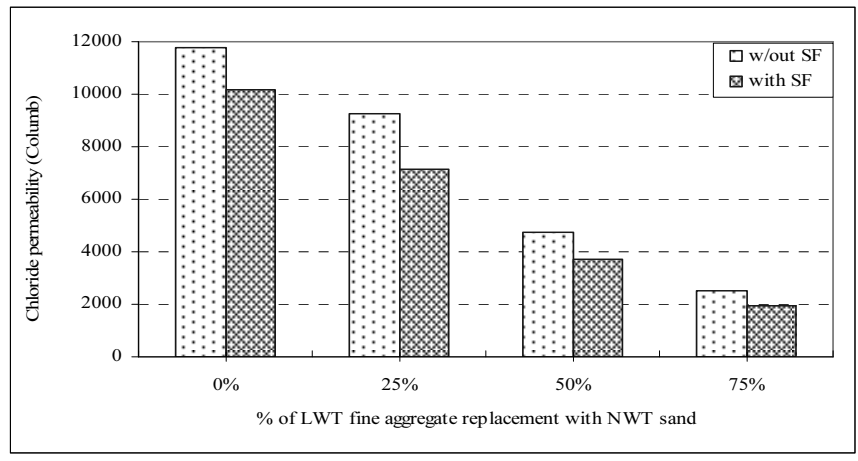

(28-day)

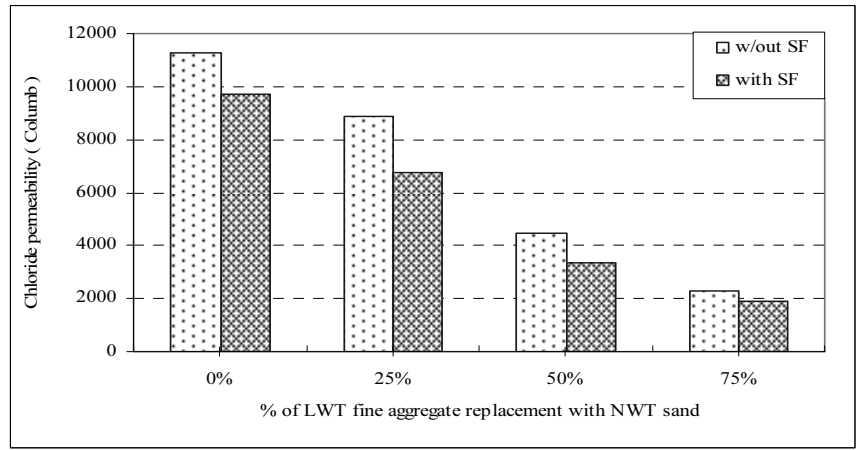

(90-day)

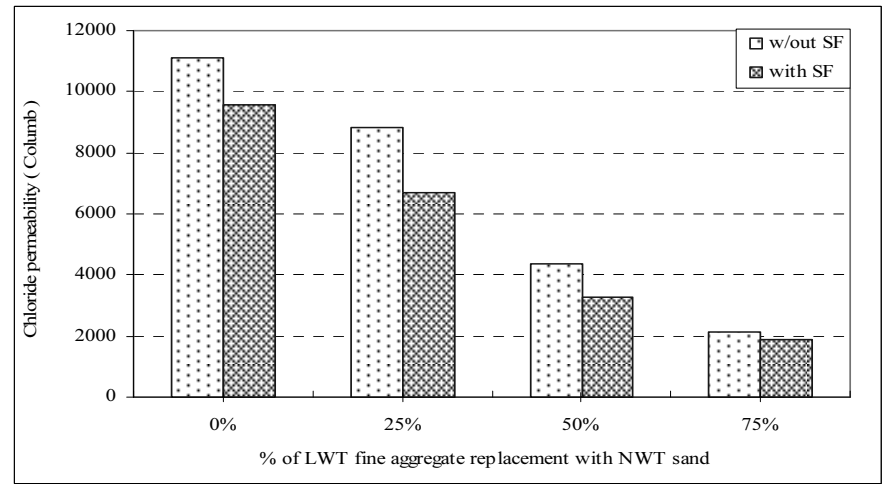

(360-day)

Fig. 2. Effect of sand replacement and silica fume on the chloride ion permeability of lightweight concrete. 
The superior performance of LWC can be attributed to the physical and chemical interaction between cement paste and aggregate. The porous texture of LWA particles enables the cement gel to grow into the aggregate surface, also enhancing the physical bond. The physical process identified was densification of the interfacial transition zone due to absorption of the aggregate.

\section{Effect of Silica Fumes Addition}

The effect of silica fume addition for different percents of sand replacement is presented also in Fig. 2 for ages of 28, 90, and 360 days. It was clear that the existence of silica fume enhanced the impermeability of concrete to the chloride ion. This attributed to the physical and chemical effects of silica fume particles, which penetrate into the open pores of the aggregate deeper than that of cement particles due to its lower viscosity and the smaller particles sizes. For lightweight aggregate of shallow outer shells, the effect may be more. Consequently decrease chloride ion permeability due to the addition of silica fume which enhancing the microstructure surface layer of aggregate.

\section{Effect of Age}

Figure 3 shows the effect of age on the performance of lightweight concrete in terms of chloride ion permeability for different sand replacement up to 360 days. It was found that the percent age of sand replacement controlled the percent age of decreasing in chloride ion permeability at different ages. Generally, the chloride ion permeability decreases as the age increases up to 360 days for all types of mixes with and without silica fame due to its chemical effects. It can be concluded that at 360 days, all types of concretes showed slightly lower chloride diffusivity than that measured at 28 days.

Leveling the results for all mixes and comparing them with the AASHTO classification is presented in Fig. 4. It was observed that the effect of age on the chloride ion permeability can be negligible for LWC. The existence of silica fume can change the level of chloride ion permeability from high to moderate level taken into consideration the effect of sand replacement.

In LWC, internal humidity is maintained at a higher level for longer period of time, resulting in a more fully hydrated cement paste. Insight of 
the above, it was found that the long-term strength development and durability of LWC will be equal to, if not superior to, NWC.
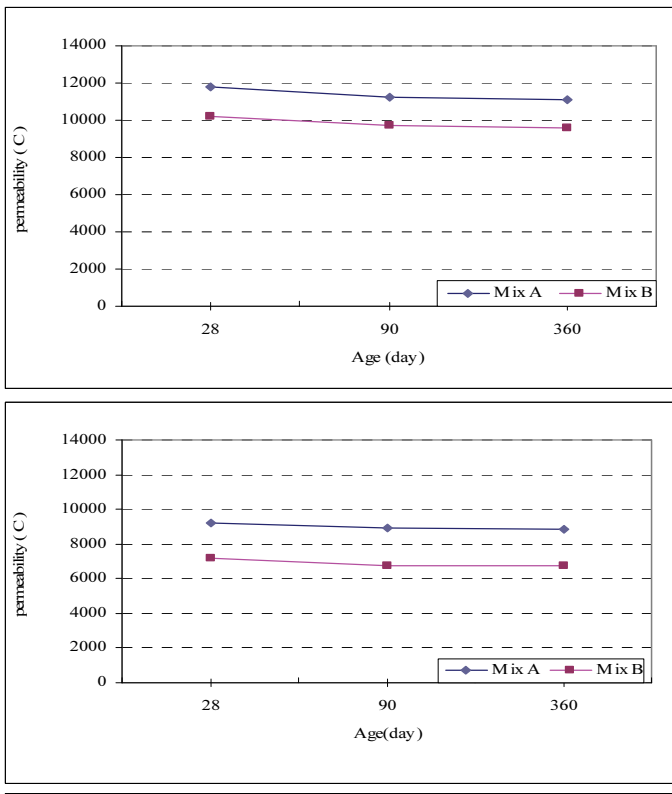

(0\% Sand)

$(25 \%$ Sand $)$

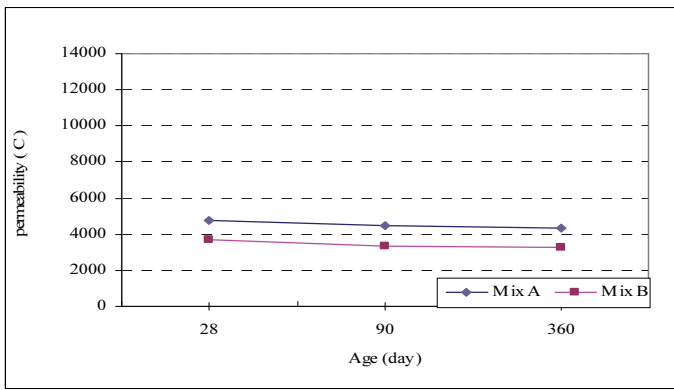

(50\% Sand)

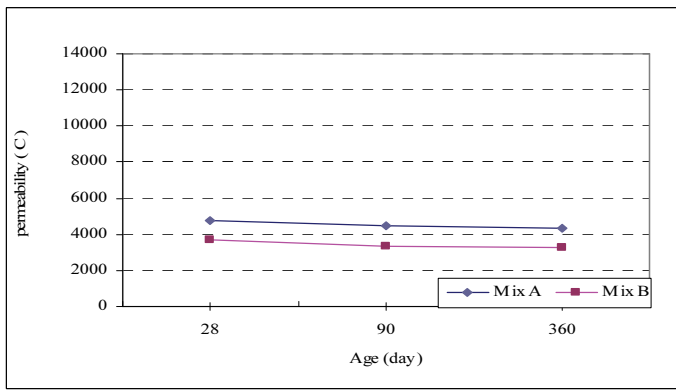

$(75 \%$ Sand $)$

Fig. 3. Effect of age on the chloride ion permeability of light weight concrete for $75 \%$ normal - weight sand. 


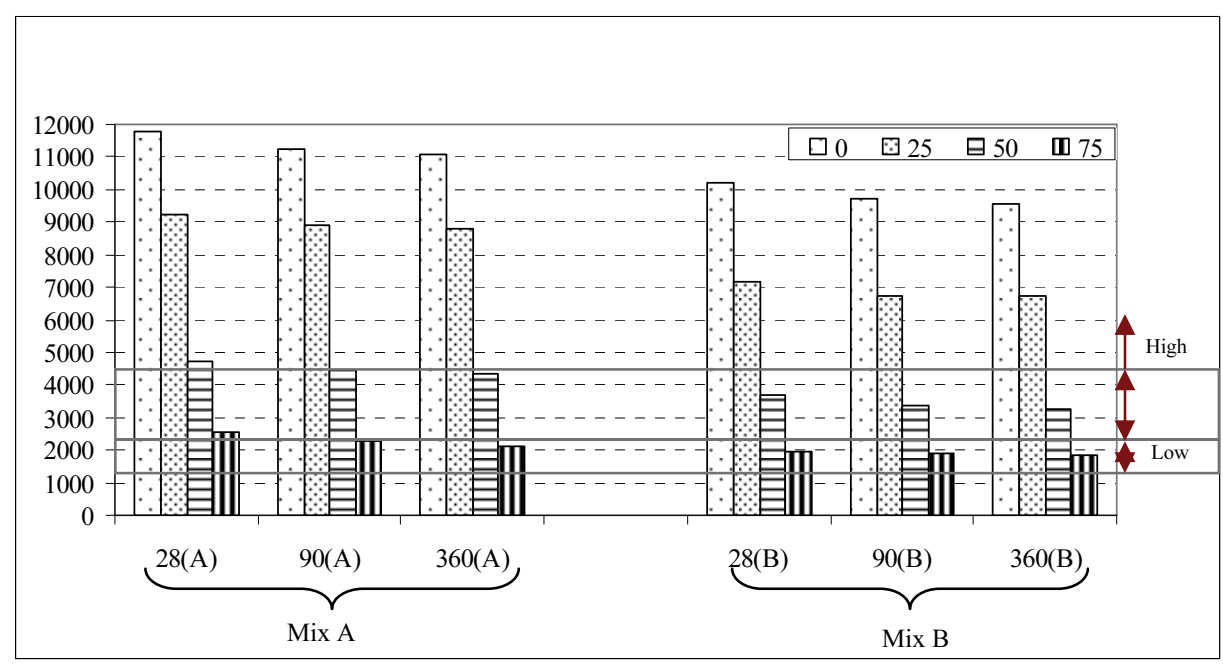

Fig. 4. Effect of sand content, silica fume and age on chloride ion permeability compared with ASHTTO.

Finally, the experimental results up to one year indicate the benefits incorporating silica fume in the lightweight concrete, with permeability being reduced significantly. The improvement attributed to the presence of the lightweight aggregate appeared to increase with maturity of the concrete. After one year continuous hydration, the reduction of chloride diffusion was clear to be as much as $20 \%$.

\section{Conclusions}

The analysis of the test results leads to the following conclusions:

1) The chloride permeability of LWC decreased with increasing sand replacement.

2) The LWC with $10 \%$ silica fume showed lower chloride diffusivities than with out silica at all levels of sand replacement.

3) At later ages (360 days), all types of concretes showed slightly lower chloride diffusivity than the equivalent measured at early ages (28 days).

4) As per the assessment criteria, all the LWC concretes containing silica fume showed a low chloride permeability of $<2000$ Coulombs. 
5) The enhancement of structural lightweight concrete permeability will improve its quality and durability, thereby exhibiting much lower corrosion rate compared to normal weight concrete.

\section{References}

[1] Rapoport, J., Aldea, C., Shah, S. P., Asce, M., Ankenman, B. and Karr, A., "Permeability of Cracked Steel Fiber-Reinforced Concrete", Journal of Materials in Civil Engineering, ASCE, 14(4) August: 355-358 (2002).

[2] Zhang, M. and Gjorv, O. E., "Permeability of High- Strength Light weight concrete", ACI Material Journal, 88(5) September: 463-469 (1991).

[3] Giorv, O.E., Tan, K. and Zhang, M., "Diffusivity of chlorides from sea water into highstrength lightweight concrete", ACI Material Journal, 91(5) September: 447-452 (1994).

[4] Chia, K.S. and Zhang, M.H., "Water Permeability and Chloride Penetration in Lightweight and Normal Weight Aggregate Concrete", ACI Material Journal, 102(2) March: 607-620 (2006).

[5] Thomas, M.D.A., "Chloride Diffusion in High- Performance Lightweight Aggregate Concrete", ACI Material Journal, 103(2) March: 797-812 (2006).

[6] Bremner, T.W., Holm, T.A. and Mcinerney, J.M., "Influence of compressive stress on concrete permeability", ACI Material Journal, 90(1) January: 345-356 (1993).

[7] Sugiyama, T., Bremner, T.W. and Holm, T.A., " Effect of stress on gas permeability in concrete", ACI Material Journal, 93(5) September: 345-356 (1996).

[8] Maage, M., Helland, S. and Arisen, J.E.C., "Modeling of chloride penetration into concrete with lightweight aggregate", ACI Material Journal, 97(4) April: 451-470 (2000).

[9] Chia, K.S. and Zhang, M., "Water permeability and chloride penetrability of high-strength lightweight aggregate concrete", Cement and Concrete Research, 32(I.4) April: 639-645 (2002).

[10] Jiang, L., Zhang, M.H. and Malhotra, V.M., "Evaluation of test methods for determining the resistance of concrete to chloride- ion penetration", ACI Material Journal, 103(4) April: $1-28$ (2004).

[11] Lo, T.Y., Cui, H.Z., Nadeem, A. and Li, Z.G., "The effects of air content on permeability of lightweight concrete", Cement and Concrete Research, 36(I. 10) October: 1874-1878 (2006).

[12] Lagerblad, B., "Normal and High Strength Concrete with Conventional Aggregate", In: Engineering and Transport Properties of the Interfacial Transition Zone in Cementitious Composites, RILEM Rep. 20, Alexander, et al. (ed.), RIELM, France, pp: 53-70 (1999).

[13] Katz, A., Bentur, A. and Kjellsen, K.O., "Normal and high Strength Concrete with Lightweight Aggregate", In: Engineering and Transport Properties of the Interfacial Transition Zone in Cementitious Composites, RILEM Rep. 20, Alexander et al. (ed.), RIELM, France, pp:71-88 (1999).

[14] Katz, A., "Treatment for Improvement of Recycled Aggregate", Journal of Materials in Civil Engineering, 597-603 (2004). 


\title{
تأثنير استبدال الرمل و إضافة غيار السيليكا على نفاذية أيون الكلور للخرسانة خفيفة الوزن
}

\author{
فائز عبدالله محمد مرزا

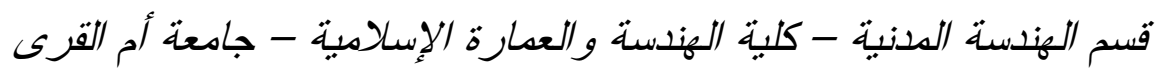 \\ مكة المكرمة - المدلكة العربية السعودية
}

المستخلص. يهذف هذا البحث إلى دراسة سلوك الخرسانة الخفيفــة

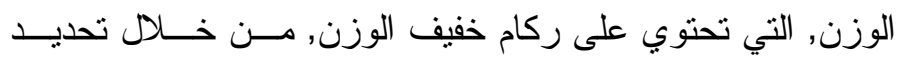
مقاومتها لنفادية أيونات الكلور بأعمار مختلفة. وقد اخذ التذ في الاعنبار

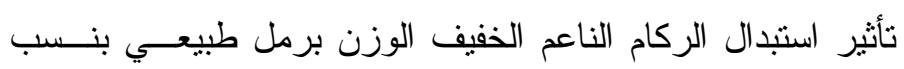

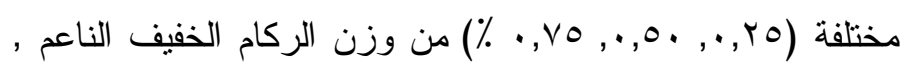

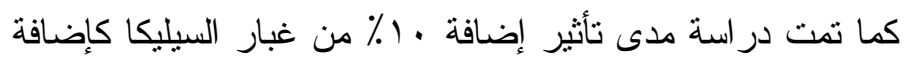

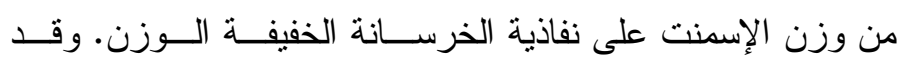

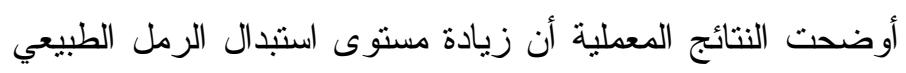

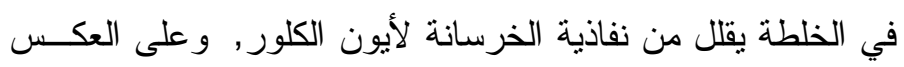

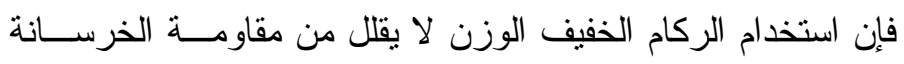

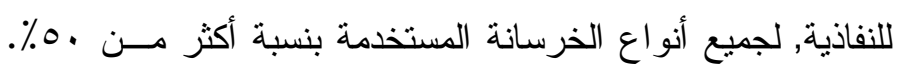
كما لوحظ أن مقاومة الخرسانة الخفيفة لنفاذية أيون الكلور تــزداد التهاد

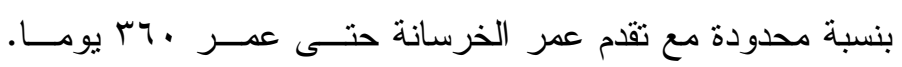

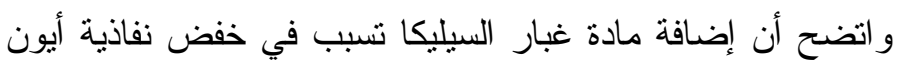

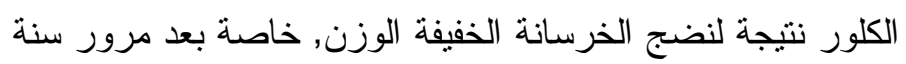

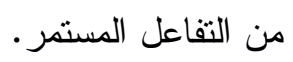

